\title{
John Murdoch Murray, B.Sc.
}

John MURDoch MURRAY died on September 30, 1939, very unexpectedly at the early age of fifty-two. He went to the University of Edinburgh from his country home in Perthshire uncertain whether to make agriculture or forestry his career. Fortunately for the latter he determined upon it. He graduated in Agriculture in March 1914 and in Forestry in the following year. He took first place in both advanced and practical Forestry at the University and generally stood well in his agriculture classes. He joined me in the War Exploitation of home woods in 191 5-16 - a duty little appreciated by either of us-and when the Forestry Commission was formed in I9I9 he became a junior District Officer, and at his death was in charge of the whole Scottish Forestry Organisation.

As a boy he gained a knowledge of field work in the woods and on the farms. He was a keen observer and combined in himself sound scientific principles with a practical sense. It fell to him to direct and instruct young foresters and he took much pleasure in helping them in many ways.

As Assistant Commissioner for Scotland, Murray had under his supervision many Officers and Foresters and a few thousand men. His treatment to all was fair, and where rebuke was necessary it was given so quietly as to make the culprit feel doubly sensible of his guilt. Forestry profited through Murray in many directions. Large areas of forest were designed and planted by him with unerring judgment of soils and conditions. It is difficult to select the best forester of this century, but in my estimation Murray would certainly have been one on a very short leet. The Forestry Commission has decided to name a plantation at Glentress near Peebles to his memory, as an appreciation to his outstanding services. Murray made a very exhaustive study of the Scots Pine, travelling all over Scotland as well as on the Continent upon this investigation. It is to be hoped that the result will not be lost and that his copious notes will later be made available to students of sylviculture.

He was elected a Fellow in 1932.

J. S. 